\title{
Southern beech (Nothofagaceae) fossil leaves from the Río Turbio Formation (Eocene-? Oligocene), Santa Cruz Province, Argentina
}

\author{
Carolina PANTI \\ Museo Argentino de Ciencias Naturales "Bernardino Rivadavia" CONICET, Av. A. Gallardo 470, C1405DJR \\ Buenos Aires, Argentina. E-mail: caropanti@gmail.com.
}

\begin{abstract}
Nothofagus sp. cf. N. obliqua, Nothofagus sp. aff. Nothofagus alessandri and Nothofagus magelhaenica are reported for the first time for the Paleogene Río Turbio Formation along with another five fossilspecies: Nothofagus simplicidens, Nothofagus variabilis, Nothofagus lanceolata, Nothofagus subferruginea and Nothofagus dicksonii. Around one hundred specimens of fossil leaves were recorded and analysed throughout the unit, but they are fairly more abundant in the upper member of the Río Turbio Formation where they reach 68\% of the overall assemblage. The observed increasing trend in Nothofagus abundance throughout the unit coincides with the beginning of the flora turnover that characterized Patagonian ecosystems from the Late Eocene onwards and it is in agreement with the marked global cooling trend of the terminal Paleogene.
\end{abstract}

Key words: Nothofagaceae, Nothofagus, Paleogene, Río Turbio, Patagonia.

Resúmen: Hojas fósiles de Nothofagus (Nothofagaceae) provenientes de la Formación Río Turbio (Eocene-?Oligocene), Provincia de Santa Cruz, Argentina. Nothofagus sp. cf. N. obliqua, Nothofagus sp. aff. Nothofagus alessandri y Nothofagus magelhaenica son registradas por primera vez para la Formación Río Turbio (provincia de Santa Cruz, Argentina) junto con otras cinco especies fósiles: Nothofagus simplicidens, Nothofagus variabilis, Nothofagus lanceolata, Nothofagus subferruginea y Nothofagus dicksonii. Alrededor de cien especímenes fósiles fueron registrados y analizados a lo largo de toda la formación, resultando ser mucho más abundantes en el miembro superior de la unidad dónde se encuentra representando el $68 \%$ de la asociación recuperada. El aumento observado en la abundancia de los ejemplares de Nothofagus a lo largo de la unidad, coincide con el comienzo del cambio florístico observado en el ecosistema patagónico que tuvo lugar a partir del Eoceno tardío siendo además coincidente con el descenso en las temperaturas globales que se registran hacia fines del Paleógeno.

Palabras clave: Nothofagaceae, Nothofagus, Paleogeno, Río Turbio, Patagonia

\section{INTRODUCTION}

Nothofagus Blume belongs to the monogeneric family Nothofagaceae and includes 43 extant species of trees (Christenhusz \& Byng, 2016) grouped in four monophyletic subgenera (Hill \& Read, 1991). The temperate subgenera (Nothofagus, Lophozonia and Fuscospora) are mainly distributed in temperate regions of the Southern Hemisphere (New Zealand, Australia and South America) with some taxa (subgenus Brassospo$\mathrm{ra}$ ) extending northward into the tropics (New Guinea and New Caledonia). In South America, Nothofagaceae is represented by 10 species, most of them deciduous, distributed in the Andean Region from $33^{\circ}$ to $56^{\circ} \mathrm{S}$ latitude, with the northern limit determined by the seasonally arid conditions of the Mediterranean climate of central
Chile (McQueen, 1976; Donoso, 1996). Below 37을 south in both, Chile and Argentina, Nothofagus occurs in two broad types of forests: temperate rainforests on climatically favourable sites, generally associated with Maytenus magellanica, Drimys winteri, Pilgerodendron uviferum and Embothrium coccineum among others and, a pure or nearly pure Nothofagus forests on less favourable sites referred to as Patagonian or Subantartic Nothofagus forests (Veblen et al., 1996). In particular, the extant vegetation of the Río Turbio area corresponds to an ecotone between the Patagonian cool temperate rainforest dominated by $\mathrm{No}$ thofagus pumilio (Poepp. \& Endl.) Krasser (Lenga) followed by Nothofagus antarctica (G.Forst.) Oerst. (Nire) (León et al., 1998; Cavallaro, 2006) and the steppe dominated by shrubs and herbs. 
The oldest fossil records of Nothofagus came from the Upper Cretaceous of Antarctica (Campanian, c. $83 \mathrm{Ma}$ ), South America and Australia (Maastrichtian, c. $70 \mathrm{Ma}$ ) and correspond to pollen grains (Romero, 1973; Archangelsky \& Romero, 1974; Dettmann et al., 1990; Dettmann, 1994; Dutra \& Batten, 2000; Moreira Muñoz, 2004). Imprints of leaves related to Nothofagus were recently mentioned by Leppe et al. (2017) from the Lower Maastrichtian of Chile but these fossils remain undescribed in detail. Confident imprints of leaves with Nothofagus affinity were recorded in the Paleocene of Antarctica (Dusén, 1908; Tosolini et al., 2013) and in the Paleocene/ Eocene boundary of central Patagonia (Okuda et al., 2006; Hinojosa et al., 2015) but the lineage only became widespread and diverse after the middle Eocene becoming more abundant during the Oligocene (Barreda \& Palazzesi, 2007; Hinojosa, 2015). Moreover, the middle Eocene-early Oligocene interval was characterized by the invasion of Nothofagus forests in Patagonia in close agreement with a marked cooling trend (Barreda \& Palazzesi, 2007). Fossil woods of Nothofagaceae were recorded from several regions in Antarctica (Poole, 2002 and references therein) and in Patagonia (Poole, 2002; Pujana, 2009; Brea et al., 2015; Pujana et al., 2015; Egerton et al., 2016; Terada et al., 2006). Records of Nothofagacean leaves from the Paleogene of Patagonia are fairly abundant (eg. Enghelhardt, 1891; Dusén, 1899; Fiori 1931, 1939, 1940; Troncoso \& Encinas, 2006; Torres et al., 2009; Panti, 2008, 2010, 2011; Vento \& Prámparo, 2016, 2018; Césari et al., 2015). In particular, for the Río Turbio Formation, fossil leaves of Nothofagus only have been mentioned and sometimes described for isolated localities (Tab. 1). This is the first attempt to analyse the record of the family throughout the entire Formation, a unit deposited during the time of expansion of Nothofagus in Patagonia.

In this paper 107 specimens referable to 8 taxonomic units of Nothofagus are described. Some of them are reported for the first time for the Río Turbio Formation. Distribution of fossil Nothofagacean leaves throughout the unit is also analysed with the aim of quantifying the dispersion of the southern beach forests in southern Patagonia during the Eocene/Oligocene.

\section{Geological Settings}

The Río Turbio Formation (RTF) (Leanza, 1972) crops out in the south western tip of Santa Cruz province, Argentina (Fig. 1) and is mainly composed of mudstones and sandstones deposited in shallow marine and estuarine environments during a period of sea level rise (Malumián et al., 2000). This sequence overlies the Early Paleocene Cerro Dorotea Formation and is separated by an erosional contact from the overlying Río Guillermo Formation (Guerstein et al., 2014). The unit was informally divided into two members: lower and upper (Malumián \& Caramés, 1997). Micro and mega-faunistic differences along with the existence of a glauconitic level at the base of the upper member point towards the presence of at least one hiatus of indefinable magnitude between both members (Malumián et al., 2000). The Río Turbio Formation is recognized in literature by its abundant fossil plant content; it includes leaves, woods and palynomorphs (Berry, 1937; Frengüelli, 1941; Hünicken, 1955, 1967, 1995; Archangelsky, 1968, 1969, 1972, Archangelsky \& Fasola, 1971; Romero, 1977; Romero \& Castro, 1986; Romero \& Zamaloa, 1985; Ancibor, 1990; Brea, 1993; Pujana, 2008; Pujana \& Ruiz, 2017; Panti, 2010, 2014a, 2018 and Fernández et al., 2012).

Evidence for the age of the RTF comes mainly from two sources. Dinoflagellates suggest an early/middle Eocene and middle/late Eocene ages for the lower and upper members, respectively (Guerstein et al., 2010; González Estebenet et al., 2015). Detrital zircon $\mathrm{U} / \mathrm{Pb}$ geochronology (Fosdick et al., 2015) restricts the lower member to the Eocene (47-46 Ma) and indicate a significantly younger age for the upper member, Eocene-Oligocene (34-27 Ma).

\section{MATERIALS AND METHODS}

The leaf imprints described in this paper were collected by the author in different outcrops where both, lower and upper members are exposed (Fig. 2). Because leaves imprints lack organic preservation, comparisons and identification of the fossil impressions were made by use of autopomorphies at species level and then at the generic level by default (Hill, 2001). The specimens with well-preserved venation were studied using modern leaf architectural analysis. Terminology and systematic descriptions follow Ellis et al. (2009) and Hickey \& Wolfe (1975). For detailed illustration and detailed analysis, specimens were photographed under unilateral lowangle light with a Nikon DS.Fi1-U2 digital camera attached to a Nikon SMZ800 stereomicroscope. Draws of the venation patterns and scaling of images were accomplished using Corel Draw X7. Suprageneric nomenclature follows APG IV 


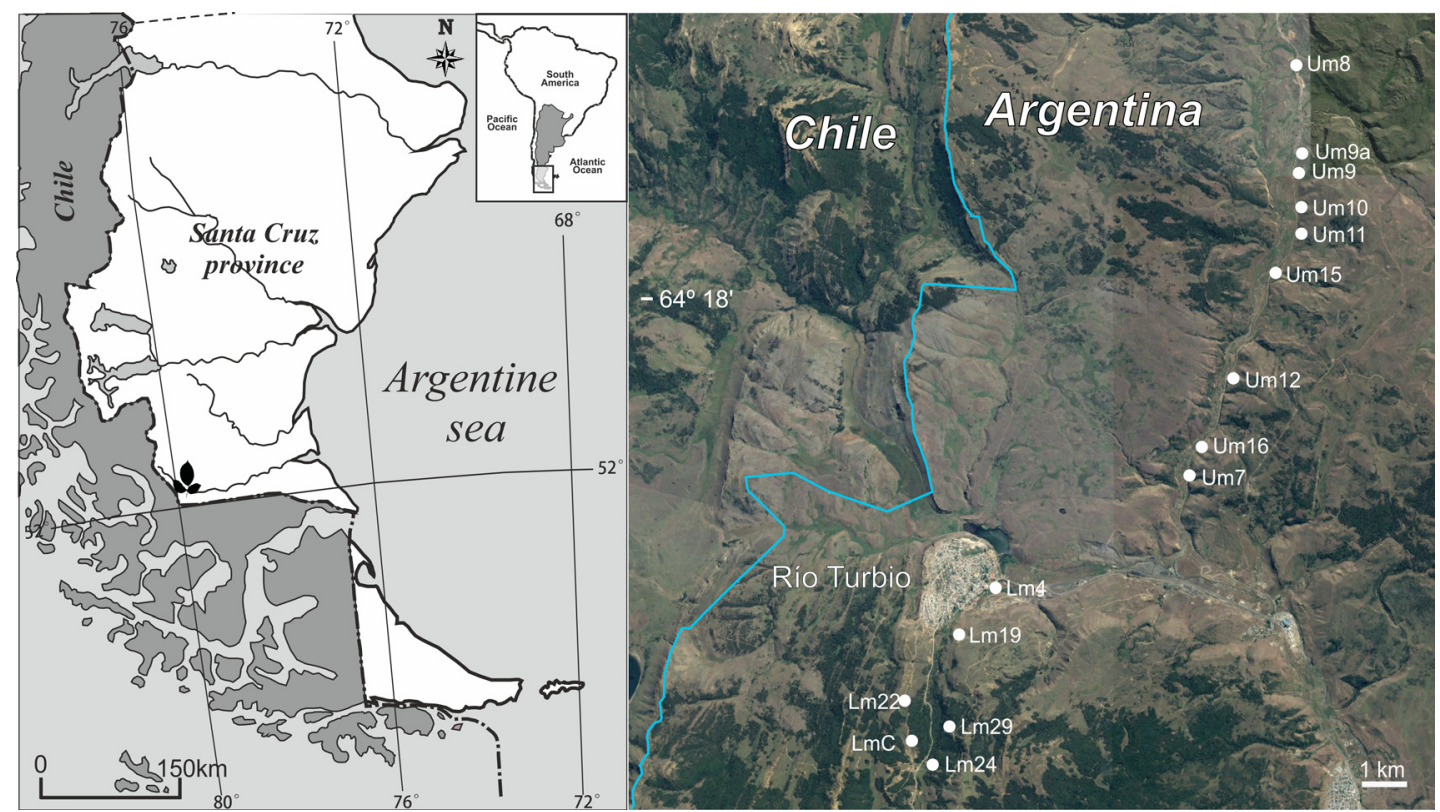

Fig. 1. Location map (A) and location-bearing samples (B). LM: Lower member; UM: Upper member.

Table 1. Species of Nothofagus mentioned and/or described for the Río Turbio Formation.

\begin{tabular}{|c|c|c|}
\hline Nothofagus species & $\begin{array}{c}\text { Presence at } \\
\text { the Río Turbio } \\
\text { Formation } \\
\end{array}$ & References \\
\hline Nothofagus australis Dusén & Upper Member & Frenguelli (1941) \\
\hline Nothofagus variabilis Dusén & $\begin{array}{l}\text { Lower and Upper } \\
\text { Member }\end{array}$ & $\begin{array}{l}\text { Berry (1937); Frenguelli (1941); Hünicken } \\
\text { (1967) }\end{array}$ \\
\hline $\begin{array}{l}\text { Nothofagus elongata Dusén emend. Romero } \\
\text { \& Dibbern }\end{array}$ & $\begin{array}{l}\text { Lower and Upper } \\
\text { Member }\end{array}$ & $\begin{array}{l}\text { Berry (1937); Frenguelli (1941); Hünicken } \\
\text { (1967) }\end{array}$ \\
\hline Nothofagus densi-nervosa Dusén & Lower Member & Hünicken (1967) \\
\hline Nothofagus subferruginea (Dusén) Tanai & $\begin{array}{l}\text { Lower and Upper } \\
\text { Member }\end{array}$ & $\begin{array}{l}\text { Berry (1937); Frenguelli (1941); Hünicken } \\
\text { (1967) }\end{array}$ \\
\hline Nothofagus simplicidens Dusén & Upper Member & Frenguelli (1941); Vento \& Prámparo (2018) \\
\hline Nothofagus dicksoni (Dusén) Tanai & Upper Member & Berry (1937); Frenguelli (1941) \\
\hline Nothofagus densinervosa Dusén & Lower Member & Hünicken (1967). \\
\hline Nothofagus serrulata Dusén & Lower Member & Hünicken (1967). \\
\hline Nothofagus lanceolata Dusén & Upper Member & Frenguelli (1941) \\
\hline Nothofagus sp & Lower Member & Hünicken (1967). \\
\hline
\end{tabular}

(2016). Plant fossils are held in the Paleobotanical Collection of the Museo Regional Padre Manuel Jesús Molina (MPM PB) located in Río Gallegos, Santa Cruz province, Argentina.

\section{RESULTS}

\section{Systematic Palaeontology}

Order FAGALES Engler, 1892

Family NOTHOFAGACEAE Kuprian, 1962
Genus Nothofagus Blume, 1851

Type species. Nothofagus antarctica (G. Forster) Oersted, 1871

The genus Nothofagus is divided into four monophyletic subgenera Brassospora Nothofagus, Lophozonia and Fuscospora, based on pollen, leaf and reproductive morphology (Dettman et al., 1990; Hill \& Read, 1991). All recently inferred phylogenies (Hill \& Jordan, 1993; Manos, 1997; 


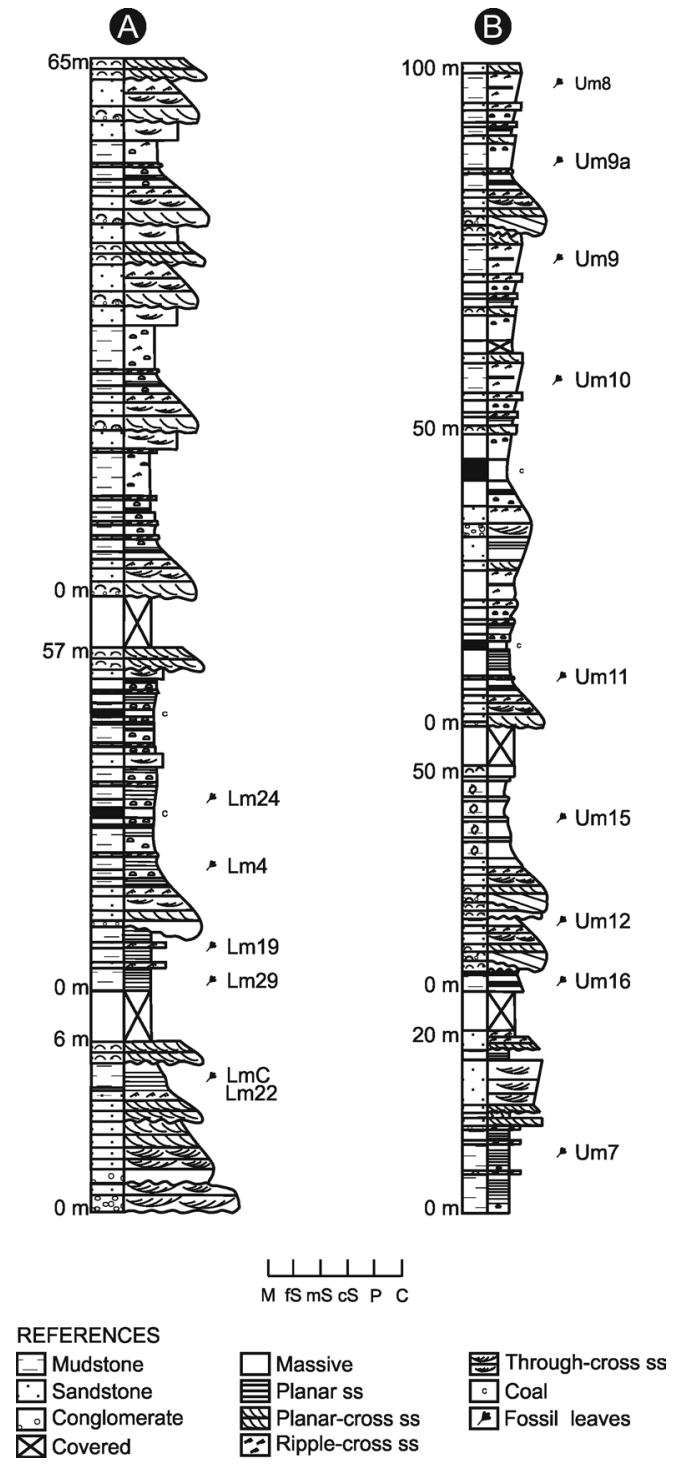

Fig. 2. Schematic log of the Río Turbio Formation showing the location of the samples. LM: Lower member (A); UM: Upper member (B).

Jordan \& Hill, 1999; Knapp et al., 2005; Sauquet et al., 2012; Vento \& Agraín, 2018) support the monophyly of these four subgenera. Recently, Vento \& Agraín (2018) tested the relationships of some South America fossil-species of Nothofagus with the four monophyletic subgenera, supporting their hypothesis that fossils Nothofagus are closely related to the modern species currently distributed in Southern Patagonia.

South American Nothofagus leaves have pinnate venation with simple craspedodromous, curved or recurved secondaries and at least one outer secondary; tertiary veins orthogonal reticulate or percurrent, highest vein order is always fifth, marginal venation is looped with open loops and areoles always small (Romero 1980, Gandolfo \& Romero 1992, Premoli 1996). Fossil leaves of Nothofagus vary from very small (less than $1 \mathrm{~cm}$ in length) to medium-sized forms (about $9 \mathrm{~cm}$ ) with rounded to acute marginal teeth, and a few to many secondary veins (Tanai, 1986). All the leaves here described are simple, with variable shape and symmetry. The margin can be serrate or crenate with simple or compound teeth. The venation is pinnate and simple craspedodromous with secondaries veins variable in number ( 7 to at least 10 pairs) and straight or curved towards the margin. The secondary veins emerge at acute angles from the midvein $\left(40^{\circ}-60^{\circ}\right)$. Tertiary veins percurrent, straight or sinuous and obtuse to the midvein. Four and fifth order veins are reticular and some have fimbrial and none, one or two agrophic veins.

Following the strict consensus tree obtained by Vento \& Agraín (2018) and based on the comparison of the fossil studied with the extant species, the fossils described where grouped according to its possible subgenus categories.

\section{Subgenus Nothofagus Hill \& Read 1991 \\ Nothofagus simplicidens Dusén, 1899}

Fig. 3(A-C), Fig. 6 (A-B)

1899 Nothofagus simplicidens Dusén, p. 100, pl. 9, figs. 20-25.

1899 Nothofagus magellanica (Engelhardt) Dusén; [part]. ibid. p. 97, pl. 10, figs. 8, 10-11 (non figs. $2,7,9)$.

1899 Nothofagus australis Dusén. ibid. p. 100, pl. 8, figs. 9-10.

1939 Nothofagus australis Dusén; Fiori, p. 49, pl. 1, fig. 14.

1939 Nothofagus cf. lanceolata Dusén; Fiori, p. 49, pl. 1, figs. 19-20.

1891 Fagus magelhaenica Engelhardt; p. 648, pl. 2, fig. 19 (non figs. 17-18).

1931 ? Fagus cf. dicksoni Dusén; Fiori, p. 112; pl. 1, fig. 13.

Material. MPM PB 3132 A-B (Lm24), MPM PB 3152 a/b (Lm29), MPM PB 3160 (Lm24); MPM PB 3001 (Um11), MPM PB 3153 B (Um7)-3154 a/b (Um9), MPM PB 3155-3157 a/b (Um9a), MPM PB 3158 (Um10)-3159 A (Um9a), MPM PB 18309 (Um11).

Description. Leaf simple, symmetrical. Laminar shape oblong to ovate, the apex wide-acute, convex, base rounded to convex. Lamina approximately $2.5 \mathrm{~cm}$ long by $1.2 \mathrm{~cm}$ wide. Petiole 
marginal. Margin toothed, serrate and crenate. Teeth simple, convex/convex, regular spaced and angular sinuses. Secondary veins ending in the simple teeth, entering along the basal side of the tooth. Venation pinnate and simple craspedodromous, the primary vein moderately thick and nearly straight. At least 7 pairs of secondary veins emerging at acute divergence angle of less than or equal to $41^{\circ}$, straight in course curving up near the margin. Tertiary order venation percurrent, straight to sinuous, with obtuse angle in relation to the midvein. Quaternary veins poorly preserved, seems to be reticulate.

Remarks. The leaf shape along with the venation pattern and the convex/convex simple tooth shape are characters that match the description of Nothofagus simplicidens. This species was formerly described by Dusén (1899) as petiolate leaves of variable size and shape, mainly oblong to oval (sometimes lanceolate) with eight to ten straight secondary veins each supplying the tooth apex. Later, Romero \& Dibbern (1985) in their revision of Nothofagus species described by Dusén add the characterization of the leaf margin formed by convex/convex simple tooth. Tanai (1986) revised the species of Nothofagus or Nothofagus-like fossil leaves from South America and West Antarctica. This author considered $N$. simplicidens distinguishable by its single-serrate margin with obtuse teeth and regularly percurrent tertiary veins with the secondary vein entering straight the main teeth along the basal side of tooth. Vento \& Prámparo (2018) mentioned the presence of Nothofagus simplicidens for the Río Turbio Formation. Their specimens are comparable to the ones here described in the leaf size and shape, the simple serrate margin, number of secondary veins and venation pattern.

According to Tanai (1986), five living South American Nothofagus species (Nothofagus alessandri, $N$. alpina, $N$. glauca, N. obliqua and N. procera) are characterized by secondary veins that enter the main teeth strait along the basal side of tooth and have percurrent tertiary veins and areoles similar to those described for $N$. simplicidens. Among all of these, the fossil-species was compared with extant $N$. obliqua (Mirb.) Oerst. from South America, despite this taxon usually has bi-serrate margin. The Patagonian Nothofagus betuloides (Mirb.) Oerst. is similar to N. simplicidens in the crenulate-serrate margin composed by simple broad teeth but, unlike the fossils, the secondary veins forks near the leaf margin.
Nothofagus variabilis Dusén, 1899

Fig. 3 (D-F), Fig. 6C

1899 Nothofagus variabilis Dusén, p. 96, pl. 9, figs. 8-13.

1967 Nothofagus variabilis Dusén form. microphylla auct. non Dusén; Hünicken, p. 167, pl. 2, figs. 3-6.

Material. MPM PB 18310-18311 (Lm24); MPM PB 2981 A (Um9a), MPM PB 2986 (Um9a), MPM PB 2989 (Um10), MPM PB 2999 (Um10) MPM PB 3002 A (Um11), MPM PB 3075 a/b (Um15), MPM PB 3076 (Um15), MPM PB 3078 (Um15).

Description. Leaf simple, symmetrical. Laminar shape ovate, the apex acute, convex, the base convex to rounded. Lamina approximately 2.5 $\mathrm{cm}$ long by $1.2 \mathrm{~cm}$ wide. Petiole marginal. Margin toothed, serrate, compound teeth irregularly spaced, principal tooth feed by main secondary vein, pointed convex/convex to straight/straight and one to tree secondary teeth irrigated by ramifications of the secondary veins with angular sinuses. Teeth seems to be glandular (Fig. 3D). Venation pinnate and simple craspedodromous, the primary vein moderately thick and nearly straight or slightly sinuous with least 5 to 7 pairs of opposite to sub-opposite secondary veins emerging at narrow divergence angle of less than or equal to $45^{\circ}$, straight in course ending at the main teeth. Tertiary order venation percurrent, with obtuse angle to the midvein, quaternary and quintenary vein both reticulate. Fimbrial vein present.

Remarks. These specimens are characterized by the double serrate margin, well developed fimbrial vein along the margin and the secondary veins entering centrally the principal teeth. These characters match the description of Nothofagus variabilis Dusén (1899, p. 96, pl. IX, figs. 8-13). These leaves are variable in their shape and size reason why Dusén defined three different forms: oblonga, subrotundata and microphylla but according to Tanai (1986) these three forms are difficult to distinguish taxonomically as independent varieties due to gradation of leaf forms that its fossil record possesses. Romero \& Dibbern (1985) also abolish these variations and they are no longer considered.

Among the extant species, Tanai (1986) related Nothofagus variabilis with N. fusca (Hook. f.) Oerst. and N. truncata (Colenso) Cockayne mainly due to "the presence of the marginal vein and the secondary veins that enter centrally the main teeth which have glandular tip" but instead, both species have simple teeth. Among the species of South America, N. variabilis shares the 

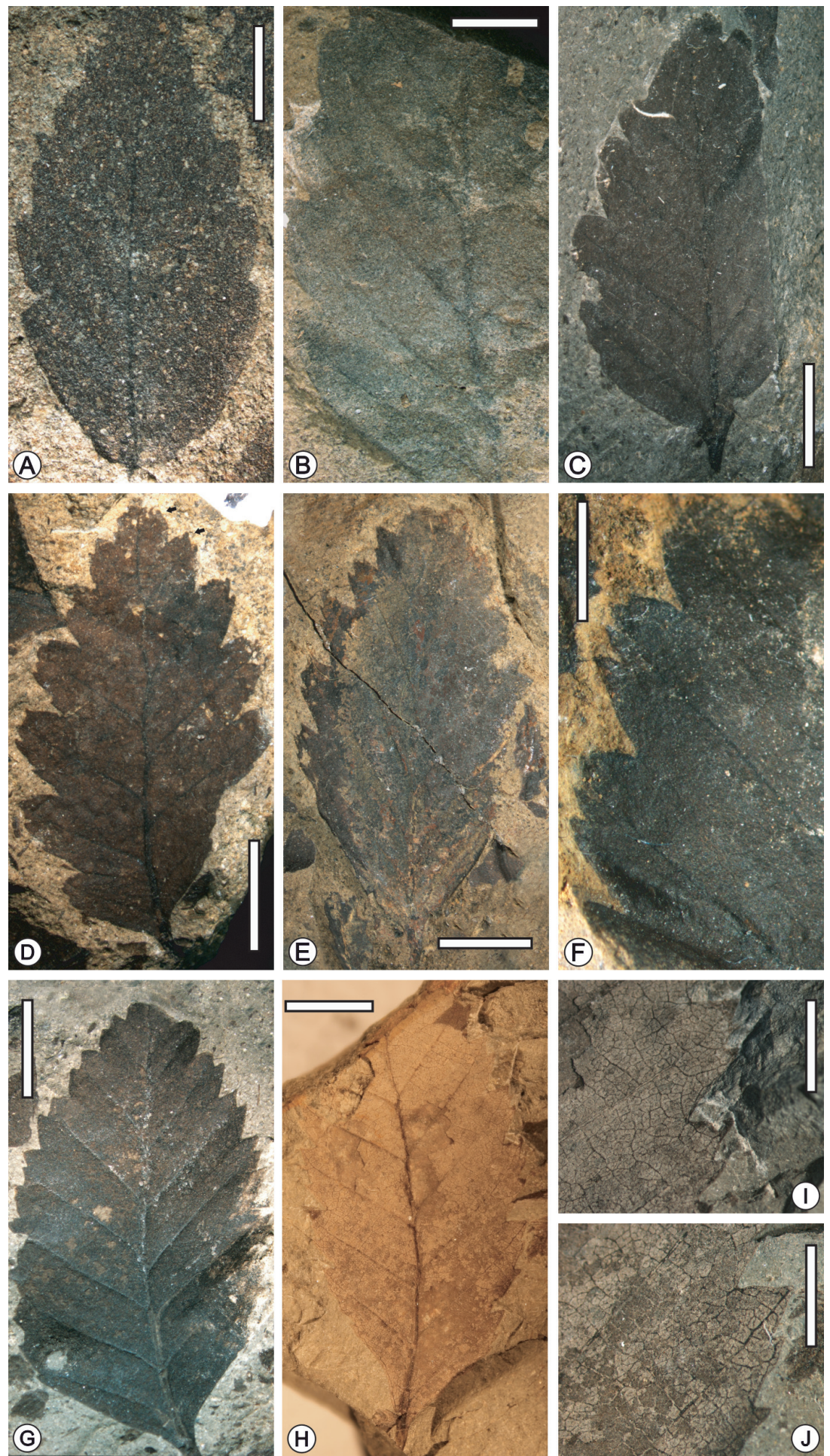

Fig. 3. A-C. Nothofagus simplicidens: A. MPM PB 3152; B. MPM PB 3160; C. MPM PB 3158. D-F. Nothofagus variabilis: D. MPM PB 3002, the arrows shows the glandular teeth and fimbrial vein; E. MPM PB 3078; F. MPM PB 3076. G-J. Nothofagus magelhaenica: G. MPM PB 2983; H-J. MPM PB 2979. All scale bars represent $5 \mathrm{~mm}$, except E-F and I-J which is $2.5 \mathrm{~mm}$. 
compound serrate margin and the presence of a fimbrial vein with $N$. dombeyi (Mirb.) Oerst. and $N$. betuloides (Mirb.) Oerst., but differs from both in the termination of the secondary veins which forks near the margin and the apical branch reaches the sinus bottom while the basal branch enters the glandular tooth apex centrally.

Subgenus Lophozonia (Turcz.) Krasser, 1896. Nothofagus magelhaenica (Engelhardt) Dusén, 1899

Fig. 3 (G-J)

1899 Nothofagus magellanica (Engelhardt) Dusén; p. 97, pl. X, figs. 2, 7-11.

1891 Fagus magelhaenica Engelhardt; p. 648, pl. 2, fig. 18 (non figs. 17, 19).

1937 Nothofagus elongata auct. non Dusén; Berry, p. 94 , pl. 18 , fig. 7 .

Material. MPM PB 2978 (Lm4); MPM PB 2979 (Um9)-2980 A-B (Um9a), MPM PB 2981 B (Um9a), MPM PB 2982 a/b (Um9a), MPM PB 2983 a/b (Um9a), MPM PB 2984-2985 (Um9a), MPM PB 2987 (Um9a)-2988 (Um10), MPM PB 2990-2998 (Um10), MPM PB 3000 (Um10), MPM PB 3003 A-B (Um11), MPM PB 3073 (Um11)3074 (Um12), MPM PB 3077 a/b (Um15), MPM PB 3112 F (Um9), MPM PB 18312-18313 (Um11), MPM PB 18314 (Um9).

Description. Leaves simple, symmetrical. Laminar shape elliptic, the apex acute, the base concave to cuneate. Lamina approximately $3 \mathrm{~cm}$ long and $1.5 \mathrm{~cm}$ wide. Petiole marginal. Margin serrate with compound teeth, principal tooth acute feed by main secondary vein, pointed convex/convex to straight. A branch from the secondary vein curves upward and supplies the apex of the subsidiary tooth. Venation pinnate and simple craspedodromous. Primary vein straight or slightly arcuate, with at least 8 pairs of opposite to sub-opposite secondary veins emerging at acute angle $\left(47^{\circ}\right)$ from the midvein, straight course. Tertiary veins opposite percurrent, straight to sinuous, with obtuse angle to the midvein. Quaternary and quinternary veins reticulate. Some specimens show plicate vernation.

Remarks. These specimens fit the description given by Tanai (1986) for N. magelhaenica, represented by elliptic leaves with acute to obtuse base, craspedodromous secondary veins diverging from the pinnate midvein at acute angles and margin serrate with two orders of teeth. Tanai (1986) accepts this combination despite she considered that all the specimens illustrated by
Dusén (1899) are single-toothed in margin and not belong to $N$. magelhaenica. Although none of the specimens described by Dusén as N. $m a-$ gelhaenica seem to have a complete margin, in some of these it is possible to infer the compound teeth by the bifurcation of the secondary vein near the margin. Both authors, Dusén and Tanai, compare the fossils of $N$. magelhaenica with the extant $N$. obliqua (Mirbel) Oerst. based on the similarities observed in their venation and marginal characters.

\section{Nothofagus sp. cf. N. obliqua (Mirb.) Oerst., 1871}

Fig. 4 (A-D), Fig. 6 (D-E)

\section{Material. MPM PB 3176-3177 (Um15).}

Description. Leaves ovate in shape, petiolate with convex base and acute apex, asymmetrical at the base, about $1.2 \mathrm{~cm}$ long by $0.6 \mathrm{~cm}$ wide ( $\mathrm{L}: \mathrm{W}$ ratio 2:1), nanophyll. Margin serrate with compound teeth, sinus shape angular, primary tooth acute whose sides are convex in the apical side and convex to straight in the basal side. The secondary veins end in the main tooth apex which is accompanied with a small subsidiary tooth in their basal side. A branch from the secondary vein curves upward and supplies the apex of the subsidiary tooth. Venation pinnate, primary vein curved, major secondary veins craspedodromous (at least 5 pairs), with regular spacing, emerging at acute angle and decurrent attachment to midvein. Basal secondary with agrophic veins developed on one side only. Intercostal tertiary veins percurrent. Plicate vernation.

Remarks. The two specimens are comparable with the extant species Nothofagus obliqua (Mirb.) Oerst and N. glauca (Phill.) Krasser but the last lacks of agrophic veins (Gandolfo \& Romero 1992). Nothofagus obliqua and the studied specimensshow unequal laminas, more than 6 secondary veins, basal secondary veins with outer secondary upon one half of the lamina, tertiary mainly alternate and the principal sinus, which separates two composite teeth, is equidistant from the two adjacent secondary veins (Gandolfo \& Romero 1992). Nothofagus cf. obliqua was defined by Dusén (1899) upon specimens that show a higher number of secondary veins. Among the fossil-species of Nothofagus, is the new samples are also comparable to Nothofagus magelhaenica in their venation and marginal characters but the specimens described have less number of secondary veins. 
Nothofagus elongata Dusén, 1899 emend. Romero \& Dibbern 1985

Fig. 4 (E-F), Fig. 6 F

1899 Nothofagus lanceolata Dusén; p. 101, pl. VIII, fig. 13.

1899 Nothofagus cf. obliqua auct non. Mirb. Dusén; p. 98. pl. X. fig. 1.

1937 Nothofagus elongata Dusén; Berry, p. 94, pl. XVIII, fig. 7.

1941 Nothofagus lanceolata Dusén; Frenguelli, p. 182, pl. IV, fig. 1.

1967 Nothofagus cf. elongata Dusén; Hünicken, p. 166, pl. 2. fig. 1 .

Material. MPM PB 3132 C (Lm24); MPM PB 3130 (Um9)-3131 (Um10), MPM PB 18316 (Um10).

Description. Leaf simple. Lamina shape elliptic to ovate, with apex acute and straight and base convex to decurrent. Lamina microphyll, approximately $2 \mathrm{~cm}$ long by $0.6 \mathrm{~cm}$ wide $\mathrm{L}: \mathrm{W}$ ratio $3: 1$. Petiole marginal. Margin serrate, teeth compound. Principal tooth feed by main secondary vein, pointed convex/convex to straight/straight and one to tree secondary teeth irrigated by ramifications of the secondary veins with angular sinuses. Venation pinnate and simple craspedodromous, the primary vein moderately thick and slightly sinuous with least 9 pairs of opposite secondary veins emerging at narrow divergence angle of less than or equal to $45^{\circ}$, straight in course ending at the main teeth. Tertiary veins hardly observables, seems to be percurrent, with obtuse angle to the midvein.

Remarks. These specimens match the description of Nothofagus lanceolata Dusén (1899, p.101, pl. VIII, fig. 13). Nothofagus lanceolata and the studied fossil leaves are quite similar in the lamina shape, venation type and toothed margin however, the specimen described by $\mathrm{Du}$ sén seems to be slightly asymmetrical towards the base (Fig. 4G).

In their revision of the Fagaceae and Nothofagaceae leaves described by Dusén(1899), Romero \& Dibbern (1985) propose that there are no differences between $N$. lanceolata and $N$. elongata. Dusén defined these two species upon the differences in their margin, base shape and number of secondary veins. According to Romero \& Dibbern (1985) both fossil-species are composed by leaves with composite teeth and similar number of secondary veins ranging from 9 to 12 representing a single species. Tanai (1986) considered $N$. lanceolata and $N$. elongata as questionable species referable to Nothofagus but still recog- nized as two different taxa which differ mainly by the presence of a compound serrate margin in $N$. lanceolata and a single serrate margin in N. elongata.

Among the extant species $N$. lanceolata was compared by Dusén with Nothofagus dombeyi but they differ in the number (higher in the fossil-species) and terminations of secondary veins (Tanai, 1986). Romero \& Dibbern (1985) mentioned Nothofagus variabilis like the most similar species being more comparable in the number of secondary veins and the presence of tertiary teeth occasionally.

Subgenus Fuscospora Hill \& Read, 1991 Nothofagus subferruginea (Dusén) Tanai, 1986 Fig. 4 (H-K), Fig. 6G

1899 Fagus subferruginea Dusén, p. 94, pl. 8, figs. 1-8. 1937 Fagus subferruginea Dusén, Berry, p. 93, pl. 18, fig. 6.

1941 Fagus subferruginea Dusén; Frenguelli, p. 180, pl. V, pl. VI, fig. 2

1967 Fagus subferruginea Dusén, Hünicken, p. 163, pl. 1, figs. 12-18.

1899 Fagus integrifolia Dusén, p. 95, pl. 8, fig. 12.

1937 Fagus integrifolia Dusén; Berry, p. 94.

1941 Fagus integrifolia Dusén; Frenguelli, p. 180, pl. $\mathrm{V}$.

1908 Fagus obscura Dusén, p. 9, pl. 1, fig. 23.

1967 Fagus obscura Dusén; Hünicken, p. 165, pl.1, fig. 19.

1940 Fagus gortanii Fiori, p. 14, pl. 5, figs. 5-6.

1940 Nothofagus cf. engelhardtiana Fiori, p. 108, pl. 5 , fig. 7.

Material. MPM PB 3089-3090 a/b (Lm4), MPM PB 3091 a/b (Lm4), MPM PB 3096 (Lm4); MPM PB 2981 (Um9a), MPM PB 3092 (Um9a)-3093 a/b A-B (Um15), MPM PB 3094-3095 (Um16), MPM PB 3097 (Um10), MPM PB 3098-3099 (Um11), MPM PB 3159 B-C (Um9a).

Description. Leaf simple. Lamina shape elliptic to ovate, with apex acute to attenuated and base wide acute to obtuse and convex to rounded in shape, slightly asymmetrical. Lamina approximately more than $6 \mathrm{~cm}$ long by $2 \mathrm{~cm}$ wide, L:W ratio $3: 1$. Petiole marginal, thick and recurved. Margin double serrated, sometimes simple serrated towards the apex, teeth regularly spaced feed by main secondary vein, pointed concave to straight/convex to concave with rounded sinuses. Venation pinnate the primary vein straight. Secondary veins simple craspedodromous, with at least 11 pairs secondary veins emerging at narrow divergence angle of $42^{\circ},\left(31^{\circ}-61^{\circ}\right)$, straight in course ending at the main teeth, one branch 

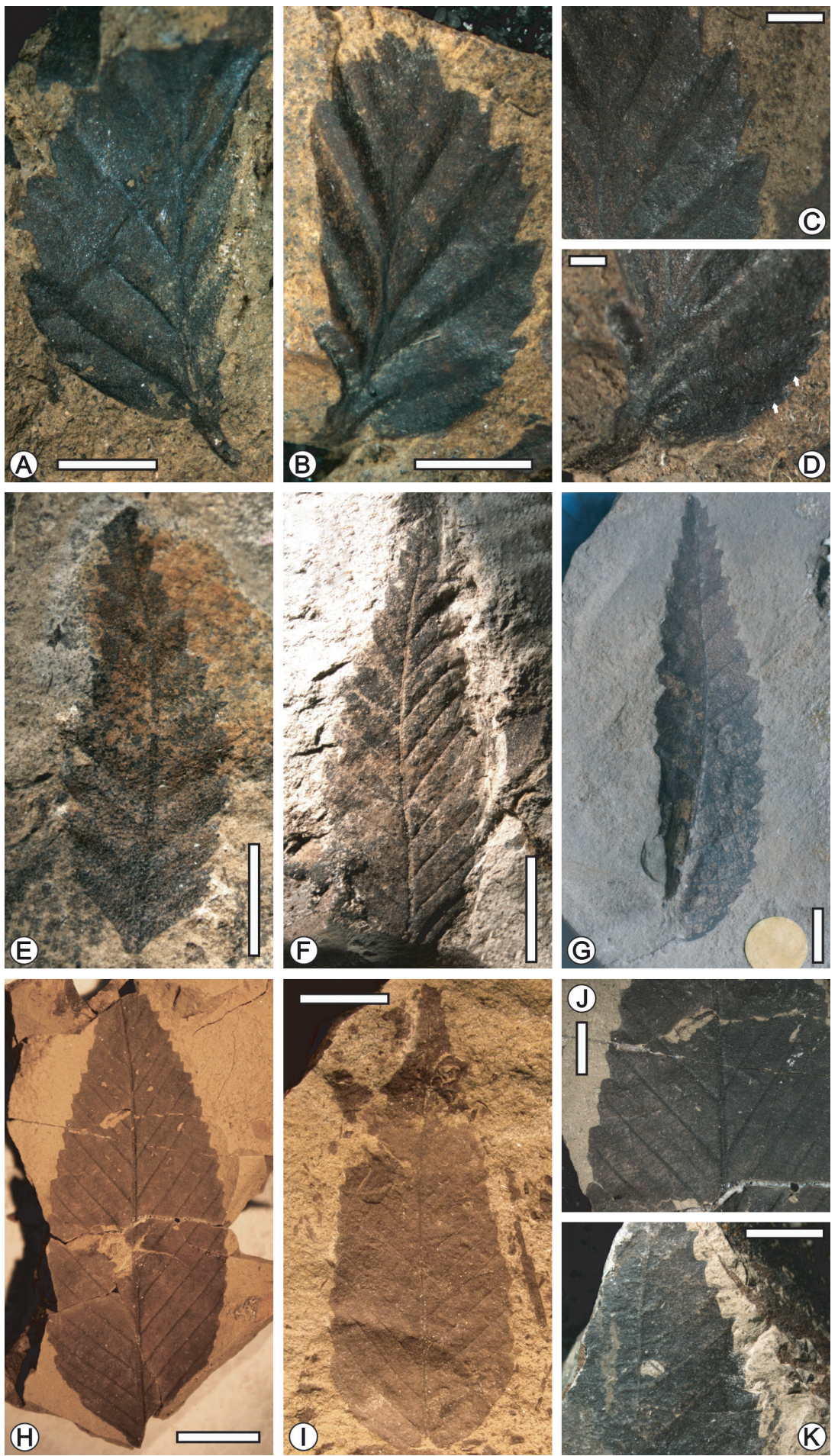

Fig. 4. A-D. Nothofagus sp. cf. N. obliqua: A. MPM PB 3177; B. MPM PB 3176, general view of the fossil leaf; C. MPM PB 3176, detail of the teeth; and D. MPM PB 3176, detail showing the outer secondary veins. E-G. Nothofagus elongata: E. MPM PB 3132; F. MPM PB 3131; G. Nothofagus lanceolata Dusén, (S165061, Swedish Museum, Stockholm). H-K. Nothofagus subferruginea: H. MPM PB 3096; I. MPM PB 3989; J. Detail of the venation of MPM PB 3096; K. MPM PB 3091. Scale bars: A-B=2.5 mm; C-D=1 mm; E-G, J-K=5mm; H-I=10 mm. 
emerging basally, and ending in a subsidiary teeth apex Secondary veins sub-opposite to alternate. Tertiary veins percurrent, obtuse to midvein. Quaternary and quinternary hardly observable, seems to be reticulate.

Remarks. Among the fossil-species, the studied specimens match the description of Nothofagus subferruginea (Dusén) Tanai in their size, shape, number of secondary veins and margin. According to Tanai (1986) leaves of $N$. subferruginea are sometimes simple toothed on the upper margin of the blade as do in the extant $N$. alessandri. This is in agreement with the specimen illustrated in the Fig. 4K. This fossil-species, formerly described as Fagus subferruginea, is a common element found in the fossil associations recovered from the Paleogene of Patagonia (see Tanai, 1986, p. 532) and Antarctica (Barton, 1964, Zastawniak, 1981, Zastawniak et al., 1985, Torres, 1990). It was emended by Tanai (1986) due to the presence of secondary veins directly entering to the teeth with one or three branching veinlets and synonymized with other "Fagus" species also described by Dusén (eg. Fagus obscura and Fagus intergifoglia). As noted by Tanai (1986) the fossils described as $N$. subferruginea are closely similar to the extant Nothofagus alessandri Espinosa in their lamina shape, venation pattern and tooth. Also, she found resemblances between $N$. alessandri and Fagus novae-zealandica Oliver and F. australis Oliver from the upper Miocene of New Zealand (Oliver, 1936) and pointed out that $N$. subferruginea and both New Zeland fossils may be closely related.

\section{Nothofagus dicksonii (Dusén) Tanai, 1986 Fig.5 (A-B), Fig. $6 \mathrm{H}$}

1899 Fagus dicksoni Dusén, p.95, pl. 8, figs. 14-16. 1908 Fagus dicksoni Dusén, p. 9, pl. 1, fig. 12. 1937 Fagus dicksoni Dusén; Berry, p. 93, pl. 18, fig. 1. 1941 Fagus dicksoni Dusén; Frenguelli, p. 180, pl. IV, fig. 4.

Material. MPM PB 2982 A, C (Um9a), MPM PB 3112 (Um9), MPM PB 3113-3115 A-B (Um9a), MPM PB 3116-3117 A-B (Um9a), MPM PB 3118-3120 A-D (Um 9a), MPM PB 3121-3125 (Um9a), MPM PB 3126 a/b (Um10), MPM PB 3127-3129 (Um10), MPM PB 3159 A-I (Um9a). Description. Leaf simple, symmetrical. Lamina shape elliptic, with apex acute and straight and base acute and cuneate to decurrent. Lamina approximately $3.5 \mathrm{~cm}$ long by $2 \mathrm{~cm}$ wide, $\mathrm{L}: \mathrm{W}$ ratio $2: 1$. Petiole marginal. Margin deeply serrated, teeth regularly spaced feed by main secondary vein, pointed convex/convex with rounded sinuses. Venation pinnate the primary vein thick and nearly straight. Secondary veins simple craspedodromous, with at least 7 pairs secondary veins emerging at narrow divergence angle of $42^{\circ}$, $\left(30^{\circ}-50^{\mathbf{o}}\right)$, straight in course ending at the main teeth. Secondary veins opposite to sub-opposite at the leaf base becoming alternate towards the apex. Tertiary veins hardly observables, seems to be percurrent. Fimbrial vein present.

Remarks. These specimens are comparable to $\mathrm{Fa}$ gus dicksonii described by Dusén (1899, p.95, pl. VIII, figs. 14-16) and characterized by "a roughly serrate margin, with regularly spaced blunt teeth separated by rounded sinus". Tanai (1986) emended the fossil-species due to the presence of large elongate teeth, secondary veins centrally entering teeth and a thick fimbrial vein along the margin, characters that according to him are not related to Fagus but to some Nothofagus.

From the Río Turbio Formation this species was described by Berry (1937) and mentioned by Frengüelli (1941) and Hünicken (1955). Recently, two fragmented specimens belonging to the Hünicken's collection were described by Vento \& Prámparo (2018) and assigned to Nothofagus sp. cf. $N$. dicksonii due to its poor preservation. The several specimens here described fit the description given for Nothofagus dicksonii sharing the prominently toothed margin and highly characteristic form of the teeth, despite the variations that can be observed in the deep of the teeth among the specimens.

According to Tanai (1986) there are no extant leaves which closely match these fossil leaves in all characters. Among the Nothofagaceae he related Nothofagus dicksoni to N. fusca (Hook. f) Oerst. and N. truncata (Colenso) Cock. despite the notorious differences in size, number of secondary veins and less conspicuous teeth.

\section{Nothofagus sp. aff. N. alessandri Espinosa.} Fig. 5 (C-E), Fig. $6 \mathrm{I}$

\section{Material. MPM PB 3175 (Lm24); MPM PB 18315 (Um11).}

Description. Leaf elliptic to ovate in shape, petiolate with obtuse and convex to rounded base, apex not preserved, at least $3.4 \mathrm{~cm}$ long and 2.4 $\mathrm{cm}$ wide, microhpyll. Margin serrate, with compound teeth, primary teeth acute whose sides are concave in the apical side and concave to flexuous on the basal side. Secondary veins end in the main tooth apex, a branch of the secondary veins seems to feed subsidiary tooth. Venation pinnate, 

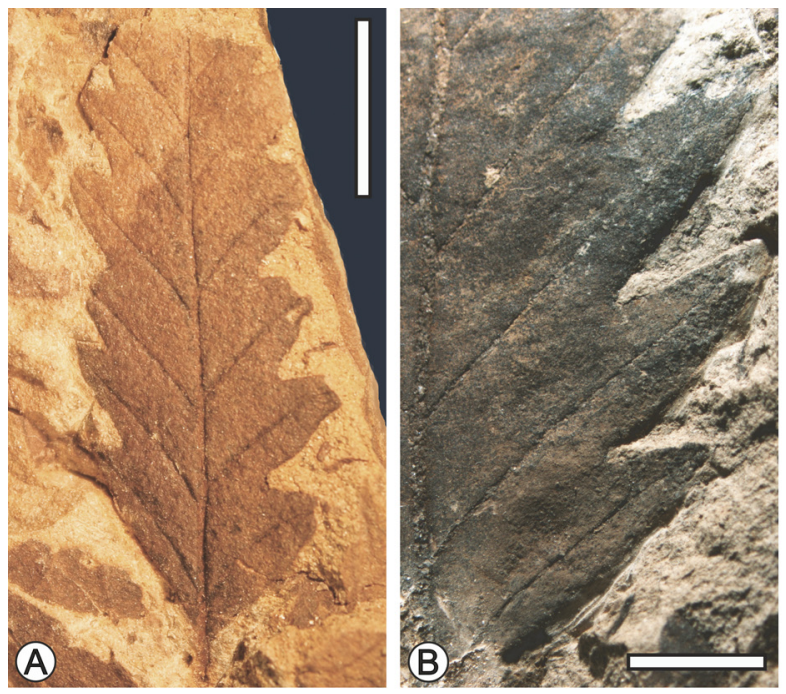

(C)
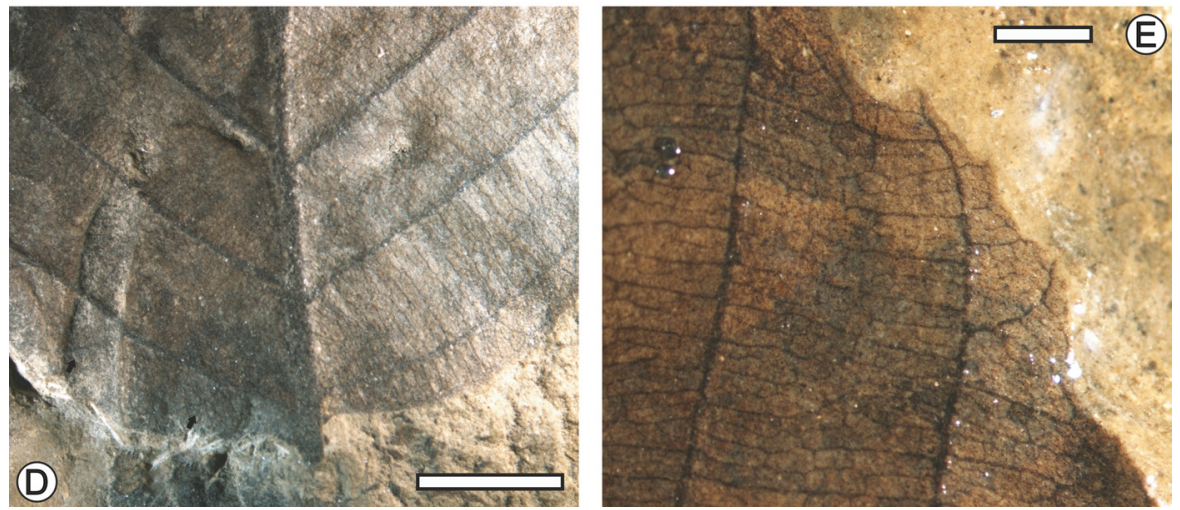

Fig. 5. A-B. Nothofagus dicksonii. A. MPM PB 3113; B. MPMP PB 3126. C-E. Nothofagus sp. aff. N. alessandri: C. MPM PB 3175, view of the fossil leaf; D. MPM PB 3175, detail showing the outer secondary veins; E. MPM PB 3175 , detail of the teeth. Scale bars: A, C=10 mm; B, D=5 mm; E=2.5 mm.

primary vein straight and stout. Major secondary veins craspedodromous (at least 6 pairs), opposite to sub-opposite, with regular spacing emerging at acute angle $\left(54^{\circ}, 43^{\circ}-74^{\circ}\right)$ from midvein. Basal secondary with simple agrophic veins developed on one side only. Intercostal tertiary veins opposite percurrent, straight to sinuous, with obtuse angle to the midvein. Quaternary vein fabric reticulate.

Remarks. Nothofagus spp. mentioned by Troncoso \& Encinas (2006, fig. 3G) seem to be similar to the specimen here described. Both share the lamina shape, margin type and the general venation pattern. Unfortunately, these specimens were not described in detail, precluding more precise comparisons.

Following the key of leaves of living species of Nothofagus developed by Gandolfo \& Romero (1992), among the species that have outer secon- dary veins the studied specimen seems to be similar to Nothofagus alessandri. They share the composite teeth, the rounded base, the presence of outer secondary veins developed only on one side of the leaf and tertiary veins percurrent. Also, both show a principal sinus, which separates two composite teeth, located just above each secondary.

\section{DISCUSSION AND CONCLUSIONS}

One hundred and seven specimens of Nothofagaceae were studied and assigned to two taxonomic units similar to extant species (Nothofagus sp. cf. N. obliqua and Nothofagus sp. aff. N. alessandri), and to six fossil-species. These are: Nothofagus simplicidens, Nothofagus variabilis, Nothofagus lanceolata, Nothofagus subferruginea, Nothofagus dicksonii and Nothofagus 


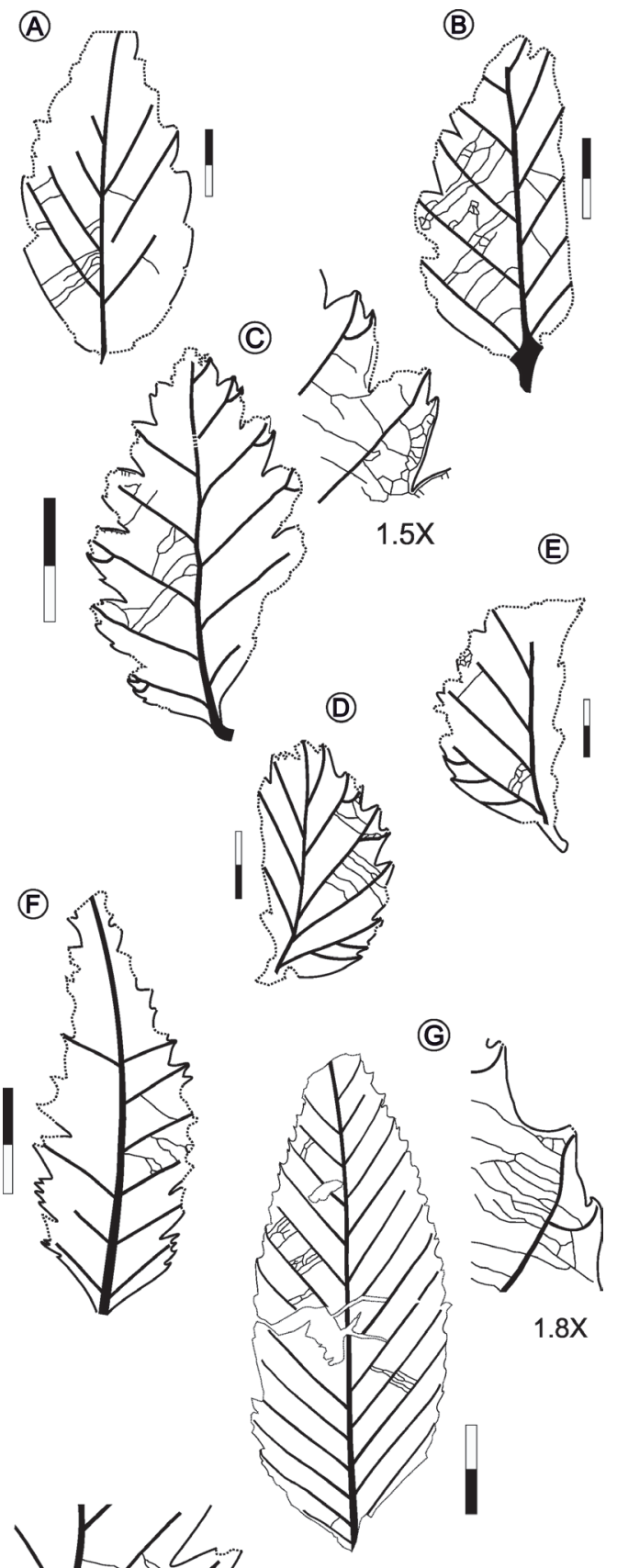

magelhaenica, being the last species reported for the first time for the unit. With few exceptions (Nothofagus dicksonii and Nothofagus sp. cf. N. obliqua) most of the Nothofagus species are present in both members of the Río Turbio Formation (Tab. 2). However, if we analysed the distribution of the specimens through the entire formation, we observed significant differences in their abundance (Fig. 6). The upper member of the RTF concentrates the $68 \%$ of the Nothofagacean specimens while in the lower member the specimens barely reaches the $17 \%$ (Fig. 7). This represents a four-time increase in the Nothofagus abundance toward the upper levels of the Río Turbio Formation.

The deposition of the Río Turbio Formation took place during a particular time-interval characterized by a progressive cooling trend estimated by climate proxy data (Zachos et al., 2001). The associations of leaves recovered from the Río Turbio Formation show a mixture of species with subtropical or tropical affinities (e.g. Lauraceae, Sapindaceae, Malpighiaceae) with others developed in cold temperate climate (see Appendix 1), mainly represented by Nothofagus (Romero, 1978, 1986a; Panti, 2014b).

Even when leaves of Nothofagus were recorded in Patagonia from the Paleocene Ligorio Marquez Formation (Hinojosa et al., 2015), they still remain absent in several associations recovered from the early Eocene (e.g. Río Pichileufú (Berry,1938), Laguna del Hunco (Berry, 1925, Wilf et al., 2003, 2005), Quinamavida (Troncoso, 1992) and the floras from Arauco, Caleta Cocholgüe and Lota Coronel, (Engelhardt, 1891; Moreno-Chacón, 2000; Moreno-Chacón et al., 2000, 2001; Gayó, 2001)). It is not until the middle Eocene-early Oligocene that the increase in abundance and diversity of Nothofagus occurs (Barreda \& Palazzesi, 2007; Hinojosa \& Villagrán, 1997; Romero, 1978, 1986b). These ancient Nothofagus forests progressively evolve through the Neogene, and they still survive in the Patagonian Andean Region.

The observed increase in the abundance of cold temperate species such as Nothofagus along

Fig. 6. Line drawings showing venation and margin details. A-B. Nothofagus simplicidens: A. MPM PB 3152; B. MPM PB 3160 . C. Nothofagus variabilis: MPM PB 3002. D-E. Nothofagus sp. cf. N. obliqua: D. MPM PB 3177; E. MPM PB 3176. F. Nothofagus elongata: MPMP PB 3132. G. Nothofagus dicksonii: MPMP PB 3126. H. Nothofagus subferruginea: MPM PB 3096. I. Nothofagus sp. aff. N. alessandri: MPM PB 3175. Scale bars: A-C, $\mathrm{F}=5 \mathrm{~mm}$; D-E, I=2.5 mm; G-H=10 mm. 
Table 2. Nothofagus species described and specimens number discriminated by member.

\begin{tabular}{lcc}
\hline \multicolumn{1}{c}{ Nothofagaceae species } & $\begin{array}{c}\text { Specimens number at the } \\
\text { Lower member }\end{array}$ & $\begin{array}{c}\text { Specimens number at the } \\
\text { Upper member }\end{array}$ \\
\hline Nothofagus simplicidens & 4 & 9 \\
Nothofagus variabilis & 2 & 8 \\
Nothofagus magelhaenica & 1 & 29 \\
Nothofagus sp. cf. N. obliqua & 0 & 2 \\
Nothofagus elongata & 1 & 3 \\
Nothofagus subferruginea & 4 & 11 \\
Nothofagus dicksonii & 0 & 31 \\
Nothofagus sp. aff. N. alessandri & 1 & 1 \\
\hline
\end{tabular}

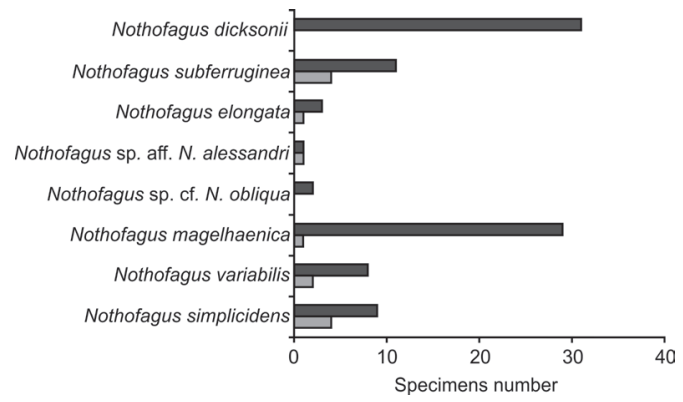

Fig. 7. Number of specimens per species discriminated by member. Dark gray, upper member; light grey, lower member.

with the decrease in richness and abundance of the megathermal taxa towards the upper member of the Río Turbio Formation (Menéndez, 1971; Panti, 2014b, 2018) would be in line with the global cooling trend. This turnover may have marked the beginning of a new floristic scenario, with a widespread cool-adapted flora across these southern latitudes.

\section{ACKNOWLEDGEMENTS}

The author would like to thank S.N. Césari, S. Marenssi, R.R. Pujana and V. Barreda for their assistance in the fieldwork, the reviewers Tania Dutra and Anne-Marie Tosolini for their valuable comments and efforts to improve the manuscript. The funds were provided by the CONICET (Argentina) [grant number PIP 2014-0259].

Appendix 1. Supplementary data to this article can be found online at http://revista.macn.gob. ar/ojs/index.php/RevMus/rt/suppFiles/626/0

\section{REFERENCES}

Ancíbor, E. 1990. Determinación xilológica de la made-
A

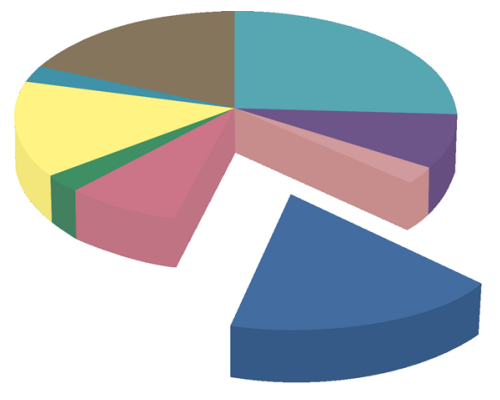

B

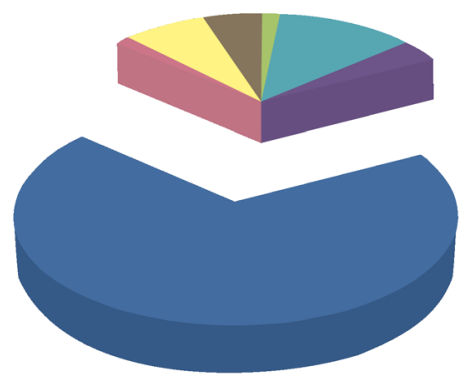

- Sapindaceae Myrtaceae

- Rhamnaceae

- Winteraceae

- Myricaceae

Fig. 8. Abundance (\%) of the specimens per family recorded at the lower (A) and upper members (B) of the Río Turbio Formation.

ra fósil de una fagácea, de la Formación Río Turbio, (Eoceno), Santa Cruz, Argentina. Ameghiniana 27(1-2): 179-184.

APG IV. 2016. An update of the Angiosperm Phylogeny Group classification for the orders and families of flowering plants. Botanical Journal of the Linnean Society 181: 1-20.

Archangelsky, S. 1968. Sobre el paleomicroplancton del 
Terciario inferior de Río Turbio, Provincia de Santa Cruz. Ameghiniana 5(10): 406-416.

Archangelsky, S. 1969. Estudio del paleomicroplancton de la Formación Río Turbio (Eoceno), provincia de Santa Cruz. Ameghiniana 6(3): 181-218.

Archangelsky, S. 1972. Esporas de la Formación Río Turbio (Eoceno). Revista del Museo de La Plata (n.s.) Sección Paleontología 6: 65-100.

Archangelsky, S. \& A. Fasola. 1971. Algunos elementos del paleomicroplancton del Terciario inferior de Patagonia (Argentina y Chile). Revista del Museo de La Plata (n.s) Sección Paleontología 6: 1-17.

Archangelsky, S. \& E.J. Romero. 1974. Los registros más antiguos del polen de Nothofagus (Fagaceae) de Patagonia (Argentina y Chile). Boletín de la Sociedad Botánica de México 33: 13-29.

Barreda, V.D. \& L. Palazzesi. 2007. Patagonian vegetation turnovers during the Paleogene-early Neogene: origin of arid-adapted floras. Botanical Review 73(1): 31-50. DOI: 10.1663/0006-8101(2007)73[31:PVTDTP]2.0.CO;2

Barton, C.M. 1964. Significance of the Tertiary fossil floras of King George Island, South Shetland Island. In: R.J. Adie (ed), Antarctic Geology, pp. 603-608. North Holland Publishing Company, Amsterdam.

Berry, E.W. 1925. A Miocene flora from Patagonia. John Hopkins University Studies in Geology 6: 183-233.

Berry, E.W. 1937. Eogene plants from Río Turbio in the territory of Santa Cruz, Patagonia. John Hopkins University Studies in Geology 12: 91-97.

Berry, E.W. 1938. Tertiary Flora from the Rio Pichileufu, Argentina. Geological Society of America, Special Papers 12: 1-149.

Blume, C.L. 1851. Museum Botanicum Lugduno-Batavum sive stirpium Exoticarum, Novarum vel Minus Cognitarum ex Vivis aut Siccis Brevis Expositio et Descriptio 1: 307.

Brea, M. 1993. Inferencias paleoclimáticas a partir del estudio de los anillos de crecimiento de leños fósiles de la Formación Río Turbio, Santa Cruz, Argentina. I. Nothofagoxylon paraprocera Ancíbor, 1990. Ameghiniana 30(2): 135-141.

Brea, M., A.E. Artabe, J.R. Franzese, A.F. Zucol, L.A. Spalletti, E.M. Morel, G.D. Veiga \& D.G. Ganuza. 2015. Reconstruction of a fossil forest reveals details of the palaeoecology, palaeoenvironments and climatic conditions in the late Oligocene of South America. Palaeogeography, Palaeoclimatology, Palaeoecology 418: 19-42. DOI: 10.1016/j. palaeo.2014.11.013

Cavallaro, S. 2006. Vegetación y Fauna. In: D. Rastelli (ed.), Estudio del Impacto Ambiental Central Termoeléctrica Río Turbio, Provincia de Santa Cruz. Servicio Geológico Minero Argentino, pp. 101-111.

Césari, S.N., C. Panti, R.R. Pujana, J.E. Francis \& S.A. Marenssi. 2015. The late Oligocene flora from the Río Leona Formation, Argentinian Patagonia. Review of Palaeobotany and Palynology 216: 143-158. DOI: 10.1016/j.revpalbo.2015.01.002.

Christenhusz, M.J.M \& J.W. Byng. 2016. The number of known plants species in the world and its an- nual increase. Phytotaxa 261(3): 201-217. DOI: 10.11646/phytotaxa.261.3.1

Dettmann, M.E. 1994. Cretaceous vegetation: the microfossil record. In: R.S. Hill (ed.), History of the Australian Vegetation, pp. 143-170. Cambridge University Press, Cambridge.

Dettmann, M.E., D.T. Pocknall, E.J. Romero \& M.C. Zamaloa. 1990. Nothofagidites Erdtman ex Potonié, 1960: a catalogue species with notes on the Paleogeographic distribution of Nothofagus Bl. (southern Beech). New Zealand Geological Survey Paleontological Bulletin 60: 79 pp.

Donoso, C. 1996. Ecology of Nothofagus Forests in Central Chile. In: T.T. Veblen, R.S. Hill \& J. Read (eds.), The ecology and biogeography of Nothofagus forests, pp. 271-292. Yale University Press.

Dusén, P. 1899. Über die tertiäre Flora der Magellanslander. In: Nordenskjöld O. (ed.), Wissenchtaftliche Ergebnisse der Schwedischen Expedition nach der Magellanslander 1895-1897, 4: 84-107.

Dusén, P. 1908. Über Die Tertiare Flora der Seymour Insel. In: Nordenskjöld O. (ed.), Wissenschaftliche Ergebnisse der Schwedischen Südpolar-Expedition 1901-1903, Geologie und Paläontologie, 3: 1-27.

Dutra, T.L. \& D.J. Batten, 2000. Upper Cretaceous floras of King George Island, West Antarctica, and their palaeoenvironmental and phytogeographic implications. Cretaceous Research 21(2-3): 181209. DOI: $10.1006 /$ cres.2000.0221.

Egerton, V.M., C.J. Williams \& K.J. Lacovara 2016. A new Late Cretaceous (late Campanian to early Maastrichtian) wood flora from southern $\mathrm{Pa}$ tagonia. Palaeogeography, Palaeoclimatology, Palaeoecology 441(2): 305-316. DOI: 10.1016/j. palaeo.2015.07.011

Ellis, B., C.D. Douglas, L.J. Hickey, K.R. Johnson, J.D. Mitchell, P. Wilf \& S.L. Wing. 2009. Manual of Leaf Architecture. The New York Botanical Garden Press and Cornell University Press, New York, 220 pp.

Engelhardt, H. 1891. Ueber Tertiärpflanzen von Chile. Senckenbergische Naturwissenschaftlichen Gesellschaft Abhandlungen 16: 629-692.

Engler, A. 1892. Syllabus der Pflanzenfamilien: eine Übersicht über das gesamte pflanzensystem mit Berücksichtigung der Medicinal-und Nutzpflanzen. Gebrüder Borntraeger Verlag, Berlin 233 pp.

Fernández, D.A., C. Panti, L. Palazzesi, \& V.D. Barreda. 2012. La presencia de una familia neotropical (Malpighiaceae) en el extremo más austral de Sudamérica durante el Eoceno. Revista Brasileira de Paleontologia 15(3): 386-391. DOI: 10.4072/ rbp.2012.3.13

Fiori, A. 1931. Fillite terziare della Patagonia. I. Fillite della rive meridionalle del Lago Nahuel Huapi. Giornale di Geologia 4: 101-106.

Fiori, A. 1939. Fillite terziare della Patagonia. II. Fillite del Río Nirihuau. Giornale di Geologia 13: 41-65.

Fiori, A. 1940. Fillite terziare della Patagonia. III. Fillite del Río Chenqueniyeu. Giornale di Geologia 14: 94-143.

Fosdick, J.C., J.E. Bostelmann, J. Leonard, R. Ugalde, 
J.L. Oyarzún \& M. Griffin. 2015. Timing and rates of foreland sedimentation: new detrital zircon U/ $\mathrm{Pb}$ geochronology of the Cerro Dorotea, Río Turbio, and Río Guillermo formations, Magallanes basin. In: Proceedings of the XIV Congreso Geológico Chileno, La Serena, Chile, 763-766.

Frenguelli, J. 1941. Nuevos elementos florísticos del Magellaniano de Patagonia Austral. Notas del Museo de La Plata, Sección Paleontología 6(30): 173-202.

Gandolfo, M.A. \& E.J. Romero. 1992. Leaf Morphology and a key to species of Nothofagus Bl. Bulletin of the Torrey Botanical Club 119(2): 152-166. DOI: $10.2307 / 2997028$

Gayó, E. 2001. Estudio taxonómico y fisionómico-climático de la tafoflora Caleta Cocholgüe $\left(36^{\circ} 35^{\prime} \mathrm{s}\right.$ y $72^{\circ} 58^{\prime}$ w), Eoceno inferior, Chile Central. PhD thesis, Universidad de Chile, Chile, 164 pp.

Gonzáles Estebenet M.S., G.R. Guerstein \& S. Casadío 2015. Estudio bioestratigráfico y paleoambiental de la Formación Río Turbio (Eoceno Medio-Superior) en el sudoeste de Patagonia (Argentina) basado en quistes de dinoflagelados. Revista Brasilera de Paleontologia 18(3): 429-442. DOI: 10.4072/ rbp.2015.3.08

Guerstein, G.R., M.S. Gonzáles Estebenet, M.I. Alperín, S.A. Casadío \& S. Archangelsky. 2014. Correlation and paleoenvironments of middle Paleogene marine beds based on dinoflagellate cyst in southwestern Patagonia, Argentina. Journal of South American Earth Sciences 52: 166-178. DOI: 10.1016/j. jsames.2014.02.011

Guerstein, G.R., M.R. Rodriguez Raising, S. Casadío, S. Marenssi \& O. Cárdenas 2010. Palinología del Miembro Inferior de la Formación Río Turbio (Eoceno inferior a medio) en el cañón del río Guillermo, suroeste de Santa Cruz, Argentina. In: Proceedings of the $\mathrm{X}$ Congreso Argentino de $\mathrm{Pa}$ leontología y Bioestratigrafía, La Plata, Argentina. Resúmenes: 93.

Hickey, L.J. \& J.A. Wolfe 1975. The bases of Angiosperm phylogeny. Vegetative morphology. Annals of the Missouri Botanical Garden 62(3): 538-589. DOI: $10.2307 / 2395267$.

Hill, R.S. 2001. Biogeography, evolution and palaeoecology of Nothofagus (Nothofagaceae): the contribution of the fossil record. Australian Journal of Botany 49: 321-332. DOI: 10.1080/03115518808619134.

Hill, R.S. \& J. Jordan. 1993. The evolutionary history of Nothofagus (Nothofagaceae). Australian Systematic Botany 6: 111-126.

Hill, R.S. \& J. Read. 1991. A revised infrageneric classification of Nothofagus (Fagaceae). Biological Journal of the Linnean Society 105(1): 37-72. DOI: 10.1111/j.1095-8339.1991.tb00199.x

Hinojosa, L.F. \& C. Villagrán. 1997. Historia de los bosques del sur de Sudamérica, I: antecedentes paleobotánicos, geológicos y climáticos del Terciario del cono sur de América. Revista Chilena de Historia Natural 70: 225-239.

Hinojosa, L.F., A. Gaxiola, M.F. Pérez, F. Carvajal, M.F Campano, M. Quattrocchio, H. Nishida, K. Uemu- ra, A. Yabe, R. Bustamante \& M.T.K. Arroyo. 2015. Non-congruent fossil and phylogenetic evidence on the evolution of climatic niche in the Gondwana genus Nothofagus. Journal of Biogeography 43(3): 555-567. DOI: 10.1111/jbi.12650.

Hünicken, M. 1955. Depósitos neocretácicos y terciarios del extremo SSW de Santa Cruz (cuenca carbonífera de Río Turbio). Revista del Instituto Nacional de Ciencias Naturales y Museo Argentino de Ciencias Naturales "Bernardino Rivadavia", Ciencias geológicas 4: 1-164.

Hünicken, M. 1967. Flora terciaria de los estratos de Río Turbio, Santa Cruz (niveles plantíferos del arroyo Santa Flavia). Revista de la Facultad de Ciencias Exactas Físicas y Naturales de la Universidad de Córdoba 27: 139-227.

Hünicken, M. 1995. Floras cretácicas y terciarias. In: P.N. Stipanicic \& M.A. Hünicken (eds.), Revisión y actualización de la obra paleobotánica de Kurtz en la República Argentina (I, II, III, IV, V, VI y VII), pp. 199-219, Academia Nacional de Ciencias, Córdoba.

Jordan, G.J., \& R.S. Hill. 1999. The phylogenetic affinities of Nothofagus (Nothofagaceae) leaf fossils based on combined molecular and morphological data. International Journal of Plant Sciences 160(6): 1177-1188. DOI: 10.1086/314207.

Knapp, M., K. Stockler, D. Havell, F. Delsuc, F. Sebastiani \& P.J. Lockhart. 2005. Relaxed molecular clock provides evidence for long-distance dispersal of Nothofagus (southern beech). PLoS Biology 3: 3843. DOI: 10.1371/journal.pbio.0030014

Krasser, F. 1896. Bemerkungen zur Systematik der Buchen. Annalen des Naturhístoríschen Hofmuseums Wien 11: 155-163.

Kuprianova, E.S. 1962. First International Conference of Palinology, Reports Sovietic Palinolinology, 21.

Leanza, A.F. 1972. Andes patagónicos australes. In: A.F. Leanza (ed.), Geología regional argentina, 689-706. Academia Nacional de Ciencias, Córdoba.

León, R.J.C., D. Bran, M. Collantes, J.M. Paruelo \& A. Soriano. 1998. Grandes unidades de vegetación de la Patagonia extra andina [Main vegetational units of the extra-andean Patagonia]. Ecología Austral 8(2): 125-144.

Leppe, M., F. Hinojosa, H. Nishida, T. Dutra, T. Wilberger, C. Trevisan, M.J. Ortuya, J.P. Pino, H. Mansilla \& V. Lobos. 2017. Asyncronic oldest record of Nothofagus leaves in Antarctica and Patagonia. Boletín de la Asociación Latinoamericana de Paleobotánica y Palinología 16: 1-321.

Malumián, N. \& A. Caramés. 1997. Upper CampanianPaleogene from the Río Turbio coal measures in southern Argentina: micropaleontology and the Paleocene/Eocene boundary. Journal of American Earth Sciences 10(2): 189-201. DOI: 10.1016/ S0895-9811(97)00015-1

Malumián, N., J. Panza, C. Parisi, C. Nañez, A. Caramés \& E. Torre. 2000. Hoja Geológica 5172-III-Yacimiento Río Turbio, Provincia de Santa Cruz, 1:250.000. Boletín del Servicio Geológico Minero 247: 108 pp. Manos, P.S. 1997. Systematics of Nothofagus (Notho- 
fagaceae) based on rDNA spacer sequences (ITS): taxonomic congruence with morphology and plastid sequences. American Journal of Botany 84(9): 1137-1155.

Mcqueen, D.R. 1976. The ecology of Nothofagus and associated vegetation in South America. Part I. Vegetation and soils in Southern Patagonia and Tierra del Fuego. Tuatara 22(1): 38-68.

Menéndez, C.A. 1971. Floras terciarias de la Argentina. Ameghiniana 8(3-4): 357-370.

Moreira Muñoz, A. 2004. Nothofagus Bl., pieza clave en la reconstrucción biogeográfica del hemisferio austral. Revista Chagual (Jardín Botánico de Santiago) 2: 48-56.

Moreno-Chacón, M. 2000. Estudio de la arquitectura foliar de Angiospermas fósiles del Paleógeno de Cocholgüe, VIII región (Chile). Tesis doctoral, Universidad de Concepción, Chile, 30 pp.

Moreno-Chacón, M., S. Palma-Heldt \& M. Leppe. 2000. Estudio de la arquitectura foliar de angiospermas fósiles del Paleógeno de Cocholgüe, VIII región (Chile). In: XII Reunión Anual de la Sociedad Botánica de Chile-XXVII Jornadas Argentinas de Botánica. Concepción, Chile. Gayana, Bot., 57: 54.

Moreno-Chacón, M., M. Leppe \& S. Palma-Heldt. 2001. Arquitectura foliar y aproximaciones paleoclimáticas de improntas del paleógeno de Cocholgüe, VIII Región, Chile. In: XIII Reunión Anual de la Sociedad de Botánica de Chile, La Serena, Chile. Gayana, Bot., 58: 71.

Oersted, A.S. 1871. Kongelige Danske videnskabernes selskabs skrifter. Naturvidensk. Math. Afd. Ser. V 4: 354 .

Okuda, M., H. Nishida, K. Uemura \& A. Yabe. 2006. Paleocene/Eocene pollen assemblages from the Ligorio Marquez Formation, Central Patagonia, XI Region, Chile. In: H. Nishida (ed.), Post-Cretaceous Floristic Changes in Southern Patagonia, Chile, pp. 37-43, Chuo University Press, Tokyo.

Panti, C. 2010. Diversidad florística durante el Paleógeno en Patagonia

Austral. Tesis doctoral, Universidad de Buenos Aires, Ciudad Autónoma de Buenos Aires, 209 pp.

Panti, C. 2011. Análisis paleoflorístico de la Formación Río Guillermo (Eoceno Tardío-Oligoceno Temprano?), Santa Cruz, Argentina. Ameghiniana 48(3): 320-335.

Panti, C. 2014a. Myrtaceae fossil leaves from the Río Turbio Formation (middle Eocene), Santa Cruz province, Argentina. Historical Biology 28(4): 459469. DOI: $10.1080 / 08912963.2014 .976635$.

Panti, C. 2014b. Paleotemperature estimations for the Río Turbio Formation (Santa Cruz, Argentina): a key for understanding the Eocene climate deterioration. In: 4th International Paleontological Congress; Mendoza, Argentina.

Panti, C. 2018. Fossil leaves of subtropical lineages in the Eocene-?Oligocene of southern Patagonia. Historical Biology, published on line 27 June 2018. DOI: $10.1080 / 08912963.2018 .1488934$.

Panti, C., S.A. Marenssi \& E.B. Olivero. 2008. Paleogene flora of the Sloggett Formation, Tierra del Fue- go, Argentina. Ameghiniana 45(4): 677-692.

Poole, I. 2002. Systematics of Cretaceous and Tertiary Nothofagoxylon: implications for southern hemisphere biogeography and evolution of the Nothofagaceae. Australian Systematic Botany 15(2): 247276. DOI: 10.1071/SB01014.

Premoli, A. 1996. Leaf architecture of South American Nothofagus (Nothofagaceae) using traditional and new methods in morphometrics. Botanical Journal of the Linnean Society 121: 25-40.

Pujana, R.R. 2008. Estudio paleoxilológico del Paleógeno de Patagonia austral (Formaciones Río Leona, Río Guillermo y Río Turbio) y Antártida (Formación La Meseta). Tesis doctoral, de la Universidad de Buenos Aires, Ciudad Autónoma de Buenos Aires, $182 \mathrm{pp}$.

Pujana, R.R. 2009. Fossil woods from the Oligocene of southwestern Patagonia (Río Leona Formation). Rosaceae and Nothofagaceae. Ameghiniana 46(4): 621-636.

Pujana, R.R. \& D.P. Ruiz. 2017. Podocarpoxylon Gothan reviewed in light of a new species from the Eocene of Patagonia. IAWA Journal 38(2): 220-244. DOI: 10.1163/22941932-20170169.

Pujana, R.R., C. Panti, J.I. Cuitiño, J.L. García Massini \& S.L. Mirabelli. 2015. A new megaflora (fossil wood, and leaves) from the Miocene of southwestern Patagonia. Ameghiniana 52(3): 350-366. DOI: 10.5710/AMGH.05.01.2014.2805.

Romero, E.J. 1968. Paleoecología y paleofitogeografía de las tafofloras del Cenofítico de Argentina y áreas vecinas. Ameghiniana 15: 209-227.

Romero, E.J. 1973. Polen fósil de Nohofagus (Nothofagidites) del Cretácico y Paleoceno de Patagonia. Revista del Museo de La Plata (Nueva serie), Sección Paleontología 7(47): 291-303.

Romero, E.J. 1977. Polen de gimnospermas y fagáceas de la Formación Río Turbio (Eoceno), Santa Cruz, Argentina. Fundación para la Educación, la Ciencia y la Cultura, Buenos Aires, 219 pp.

Romero, E.J. 1978. Paleoecología y paleofitografía de las tafofloras del Cenofítico de Argentina y áreas vecinas. Ameghiniana 15(1-2): 209-227.

Romero, E.J. 1980. Arquitectura foliar de las especies sudamericanas de Nothofagus Bl. Boletín de la Sociedad Argentina de Botánica 19 (1-2): 289-308.

Romero, E.J. 1986a. Paleogene phytogeography and climatology of South America. Annals of the Missouri Botanical Garden 73(2): 449-461.

Romero, E.J. 1986b. Fossil evidence regarding the evolution of Nothofagus Blume. Annals of the Missouri Botanical Garden 73(2): 276-283.

Romero, E.J. \& M.J. Castro. 1986. Material fúngico y granos de polen de angiospermas de la Formación Río Turbio (Eoceno), provincia de Santa Cruz, República Argentina. Ameghiniana 23(1-2): 101118.

Romero, E.J \& M.C. Dibbern, 1985. A review of the species described as Fagus and Nothofagus by Dusén. Palaeontographica B 197: 123-137.

Romero, E.J \& M.C. Zamaloa. 1985. Polen de angiospermas de la Formación Río Turbio (Eoceno), 
provincia de Santa Cruz, República Argentina. Ameghiniana 22(1-2): 43-51.

Sauquet, H., S.Y. Ho, M.A. Gandolfo, G.J. Jordan, P. Wilf, D. Cantrill, M.J. Bayly, L. Bromham, G. Brown, R. Carpenter, D. Lee, D. Murphy, J.M. Kale Sniderman \& F. Udovicic. 2012. Testing the impact of calibration on molecular divergence times using s fossil-rich group: the case of Nothofagus (Fagales). Systematic Biology 61: 289-313.

Tanai, T. 1986. Phytogeographic and phylogenetic history of the genus Nothofagus Bl. (Fagaceae) in the southern hemisphere. Journal of the Faculty of Science, Hokkaido University Series IV 21: $505-582$.

Terada, K., T.O. Asakawa \& H. Nishida. 2006. Fossil wood assemblage from Cerro Dorotea, Última Esperanza, Magallanes (XII) region, Chile. In: H. Nishida (ed.) Post-Cretaceous floristic changes in southern Patagonia, Chile, pp. 67-90, Faculty of Science and Engineering, Chuo University.

Torres, T.G. 1990. Étude Paléobotanique du Tertiare des îles Roi Georges et Seymour, Antarctique. PhD thesis, Université Claude-Bernard, Lyon, $210 \mathrm{pp}$.

Torres, T.G., M. Cisterna, A. Llanos, H. Galleguillos \& J.P. Le Roux. 2009. Nuevos registros de Nothofagus Bl. en Sierra Baguales, Última Esperanza, Patagonia, Chile. In: XII Congreso Geológico Chileno, Santiago, Chile. Extended Abstracts, S12-S19.

Torres, T.G., N.M. Gutiérrez, E. Bostelmann, J.P. Le Roux, J.L. Oyarzún, R. Ugalde, R. Otero \& F. Hervé 2013. Exceptionally preserved fossil flora of the Río Leona Formation in Sierra Baguales, Magallanes, Chile: insights into the early Neogene Patagonian ecosystems. Geosur 352-355.

Tosolini, A.M.P., D.J. Cantrill \& J.E. Francis. 2013. Paleocene flora from Seymour Island, Antarctica: revision of Dusén's angiosperm taxa. Alcheringa 37(3): 366-391.

Troncoso, A. 1992. La tafoflora terciaria de Quinamavida (VII Región, Chile). Boletín del Museo de Historia Natural de Chile 43: 155-178.

Troncoso, A. \& A. Encinas. 2006. La tafoflora de cerro Centinela (Chile, VI Región): vegetación y clima de Chile central a fines del Mioceno-comienzos del Plioceno. Ameghiniana 43(1): 171-180.

Veblen, T.T., C. Donoso, T. Kitzberger \& A.J. Rebertus. 1996. Ecology of Southern Chilean and Argenti- nean Nothofagus Forests. In: T.T. Veblen, R.S. Hill $\&$ J. Read (eds.), The ecology and biogeography of Nothofagus forests, pp. 293-353.

Vento, B. \& F.A. Agraín. 2018. Phylogenetic relationships and time-calibration of the South American fossil and extant species of southern beeches ( $\mathrm{No}$ thofagus). Acta Palaeontologica Polonica 63 (4): $815-825$.

Vento, B. \& M. Prámparo. 2018. Angiosperm association from the Río Turbio Formation (Eocene?Oligocene) Santa Cruz, Argentina: revision of Hünicken's (1955) fossil leaves collection. Alcheringa published online 7 January 2018. DOI: 10.1080/03115518.2017.1408854.

Vento, B., M.A. Gandolfo, K.C. Nixon \& M. Prámparo. 2016. Paleofloristic assemblage from the Paleogene Río Guillermo Formation, Argentina: preliminar results of phyogenetic relationships of Nothofagus in South America. Historical Biology 29(1): 93-107. DOI: $10.1080 / 03115518.2017 .1408854$.

Wilf, P., N.R. Cúneo, K.R. Johnson, J.F. Hicks, S.L. Wing \& J.D. Obradovich 2003. High Plant Diversity in Eocene South America: Evidence from Patagonia. Science 300(5616): 122-125.

Wilf, P., K.R. Johnson, R. Cúneo, E. Smith, B.S. Singer \& A. Gandolfo. 2005. Eocene plant diversity at Laguna del Hunco and Río Pichileufú, Patagonia, Argentina. The American Naturalist 165(6): 634-650.

Zachos, J., M. Pagani, L. Sloan, E. Thomas \& K. Billups. 2001. Trends, rhythms, and aberrations in global climate $65 \mathrm{Ma}$ to present. Science (5517), 292: 686-693.

Zastawniak, E., 1981. Tertiary leaf flora from the Point Hennequin Group of King George Island (South Shetland Islands, Antarctica). Preliminary Report. Geological Results of the Polish Antarctic Expeditions 72: 97-112.

Zastawniak, E., R., Wrona, A. Gazdzicki \& K. Birkenmajer. 1985. Plant remains from the top part of the Point Hennequin Group (Upper Oligocene), King George Island (South Shetland Islands, Antarctica). Geological Results of the Polish Antarctic Expeditions 81: 143-170.

Doi: 10.22179/REVMACN.21.626

Recibido: 7-II-2019

Aceptado: 13-VI-2019 